\title{
MOBILNOŚĆ JAKO POTENCJALNOŚĆ: SPOSOBY ROZUMIENIA MOBILNOŚCI Z PERSPEKTYWY NOWYCH TECHNOLOGII I PARADYGMATU MOBILNOŚCI
}

Mobilność jako pojęcie, proces i praktyka społeczna zyskuje coraz większe znaczenie we współczesnym świecie. Zbyt często jednak rozumienie mobilności jest upraszczane i sprowadzane wyłącznie do praktyk indywidualnego lub zbiorowego przemieszczania się. Z tego powodu celem niniejszego artykułu jest wskazanie, że mobilność ma charakter społeczny i tym samym społecznie konstruowany, co zostanie opisane na dwóch poziomach. Pierwszy z nich to refleksja nad tym, w jaki sposób mobilność, w szczególności technologie mobilne, wpływają na zmiany sposobów rozumienia pojęć i zjawisk społecznych. Drugi cel to opisanie społecznych sposobów rozumienia pojęcia „mobilność” w odniesieniu do nowych technologii i wskazanie, że jest ona traktowana nie tylko jako praktyka, lecz bardziej jako potencjalność - cecha charakteryzujacca działania podejmowane przez różnych aktorów życia społecznego. Aby to jednak było możliwe, konieczne jest odniesienie się do podstawowych cech paradygmatu mobilności jako perspektywy teoretycznej badanych zjawisk.

\section{PARADYGMAT MOBILNOŚCI JAKO PERSPEKTYWA TEORETYCZNA OPISU WSPÓŁCZESNEGO ŻYCIA SPOŁECZNEGO}

Tradycyjnie rozumiana socjologia (i szerzej: nauki i badania społeczne) jest postrzegana jako statyczna ${ }^{1}$. Z jednej strony oznacza to przyjęcie specyficznej perspektywy epistemologicznej, w której nieruchomy badacz próbuje poznać nieruchomy przedmiot swoich zainteresowań, z drugiej - pokazuje to niedowartościowanie znaczenia i roli różnego rodzaju form mobilności i przemieszczania się jako zjawisk marginalnych i raczej przerw pomiędzy bardziej interesującymi badawczo aktywnościami.

Odpowiedzia na takie postawy jest new mobilities paradigm - paradygmat (nowych) mobilności ${ }^{2}$. Określanie go mianem paradygmatu sugeruje, że nie jest to tylko nurt zainteresowań nowymi zjawiskami społeczno-kulturowymi,

${ }^{1}$ Ł. Rogowski, Wideozwiedzanie. Badania miasta w perspektywie paradygmatu mobilności, „Kultura i Społeczeństwo” 2016, nr 3(91), s. 85.

${ }^{2}$ M. Scheller, J. Urry, The new mobilities paradigm, „Environment and Planning” 38, 2006. 
lecz bardziej całościowa propozycja teoretyczna i metodologiczna. Zadaniem, które sobie ona stawia, jest „badanie przemieszczania się, zablokowanego ru$\mathrm{chu}$, potencjału przemieszczania i nieruchomości, zamieszkiwania i wytwarzania miejsca"’3. Taki cel oparty jest jednak na bardziej ogólnych założeniach: mobilność jest tu traktowana nie tylko jako określone działanie, ale jako układ aktorów i zdarzeń, które konstytuują relacje ekonomiczne, polityczne i społeczne ${ }^{4}$. Oznacza to, że w ramach badanych obszarów moga powstawać całkowicie nowe zjawiska społeczne, niedostrzegalne wtedy, gdy przyjmuje się statyczna perspektywę oglądu społecznej rzeczywistości. Swój udział w tym ma metodologia badań mobilnych, która wypracowała i stosuje techniki badawcze dostosowane do opisywanego paradygmatu. Pozwala to również na wyróżnienie nowych wymiarów tradycyjnie rozumianych i badanych zjawisk społecznych, np. wtedy, gdy mobilność jest traktowana jako nierównomiernie dystrybuowany zasób ${ }^{5}$, a tym samym nowy aspekt nierówności społecznych. W takim ujęciu paradygmat mobilności zbliża się do perspektywy proponowanej przez teorię sieci społecznych i do analiz sieciowych. Zwraca jednak w większym stopniu uwagę na przepływy aktorów i dóbr niż na węzły, pomiędzy którymi owe przepływy się dokonuja. Dla obu tych perspektyw wspólne jest przekonanie, że bliskość przestrzenna nie jest wcale najważniejszym elementem wyznaczającym wytwarzanie i przebieg relacji społecznych ${ }^{6}$.

Oczywiście nie oznacza to jednak negowania znaczenia przestrzeni w procesach mobilności. Sa one zawsze zlokalizowane i zmaterializowane ${ }^{7}$. Pozostają więc w związku z fizycznymi aspektami miejsca, w którym się realizuja, co wyznacza zarówno przebieg, jak i zróżnicowanie form mobilności. To nie tylko chodzenie czy jeżdżenie, ale również choćby wspinanie się, analizy środków transportu czy też infrastruktury organizującej przemieszczanie się. Rozszerzając zakres rozumienia mobilności, Monika Büscher, John Urry i Katian Witchger wskazują pięć jej typów: podróże cielesne (odnoszące się do ludzi), ruch fizyczny (związany z przedmiotami), podróże wyobrażeniowe (odbywane na podstawie rozmów czy obrazów), podróże wirtualne (wykorzystujące zapośredniczenie technologiczne, np. w grach komputerowych) oraz podróże komunikatywne (związane z wymianą informacji pomiędzy ludźmi, np. za pośrednictwem listów, kartek pocztowych albo SMS-ów) ${ }^{8}$. W takim ujęciu mobilność dotyczy nie tylko ludzi, ale również przedmiotów, obrazów, informacji czy odpadów ${ }^{9}$. Paradygmat mobilności ma więc o tyle charakter całościowy, o ile rozszerza badany przez nauki społeczne zbiór aktorów życia społecznego.

${ }^{3}$ M. Büscher, J. Urry, K. Witchger, Introduction. Mobile methods, w: eidem, K. Witchger, Mobile Methods, New York 2011, s. 2 (tłum. Ł.R.).

${ }^{4}$ Ibidem, s. 4.

${ }^{5}$ J. Frith, Splintered space: hybrid spaces and differential mobility, „Mobilities” 7(1), 2012, s. 134.

${ }^{6}$ Y. Takhteyev, A. Gruzd, B. Wellman, Geography of Twitter networks, „Social Networks” 34, 2012, s. 73 .

${ }^{7}$ M. Scheller, J. Urry, op. cit., s. 210.

${ }^{8}$ M. Büscher, J. Urry, K. Witchger, op. cit., s. 5.

9 J. Urry, Socjologia mobilności, tłum. J. Stawiński, Warszawa 2009, s. 11. 


\section{MOBILNOŚĆ I TECHNOLOGIE MOBILNE JAKO ELEMENT KSZTAŁTUJĄCY SPOŁECZNE ZNACZENIA}

U podstawowych założeń paradygmatu mobilności leży przekonanie, że istnieje zależność pomiędzy nowymi formami koordynowania ludzi, miejsc i wydarzeń a rozwojem technologicznym ${ }^{10}$. Z jednej strony chodzi tu oczywiście o te wszystkie sytuacje, w których technologie wpływają na przebieg procesów przemieszczania. Ma to związek z nowymi pojazdami, wykorzystywana przez nie nowa infrastruktura, z nowymi sposobami koordynowania transportu ludzi i towarów. Z drugiej strony, co istotniejsze z punktu widzenia niniejszego tekstu, to również zmiany sposobów rozumienia zjawisk społecznych, uzależnione od przemian mobilności i technologii mobilnych. Można iść tu tropem Neila Postmana, który stwierdza, że technologie zmieniają sposoby rozumienia pojęćc ${ }^{11}$. Co za tym idzie, również zapośredniczone technologicznie nowe formy mobilności informacji, wiedzy, znaczeń czy obrazów. Dlatego warto wskazać na trzy najważniejsze pojawiające się w literaturze obszary opisujace relacje technologia - mobilność - społeczne znaczenia.

Po pierwsze, przemiany mobilności zmieniają sposoby rozumienia przestrze$n^{12}$. Punktem wyjścia jest tutaj możliwość komunikacji niezależnie od połączeń fizycznych i kabli. Ma ona bez watpienia rewolucyjny charakter, gdyż takie przesyłanie informacji na odległość nie tylko usprawniło procesy komunikacji, ale też wpłynęło na zmiany świadomościowe. Podstawowym uwarunkowaniem łączności i komunikacji stała się już nie bliskość fizyczna, ale jakość łącz technologicznych. W ten sposób również więzi społeczne skierowały się, obok uwarunkowań geograficzno-przestrzennych, ku uwarunkowaniom technologicznym. Te zjawiska, jakkolwiek obecne już na etapie rozwoju nowych mediów i Internetu, osiagnęły swoją kulminację wraz z rozwojem technologii mobilnych, określanym nie bez powodu przez Lee Raine’a i Barry'ego Wellmana mianem „rewolucji mobilnej"13. Zwracają oni uwage na trzy kwestie istotne z punktu widzenia modyfikacji postrzegania i znaczenia przestrzeni wraz z rozwojem technologii mobilnych. Po pierwsze, lokalizacja konkretnej jednostki staje się punktem odniesienia innych lokalizacji. „Tutaj” jest jednoznaczne z miejscem, w którym znajduję się wraz z moim smartfonem. Po drugie, przemieszczanie się w przestrzeni ze smartfonem skutkuje mniejszym lub większym ignorowaniem tego, co dzieje się w bezpośrednim otoczeniu fizycznym. Technologie mobilne intensyfikują w ten sposób tzw. efekt walkmana ${ }^{14}$, który polega na koncentrowaniu się nie na bodźcach pochodzaccych z bezpośredniego otoczenia fizyczno-przestrzennego, ale na dostarczanych technologicznie wrażeniach. Technologie mobilne skutkują więc raczej izolacją od przestrzeni i „byciem-gdzieś-indziej” niż zanurzeniem w przestrzeń, Po trzecie, dzięki technologiom mobilnym przestrzeń za-

${ }^{10}$ M. Scheller, J. Urry, op. cit., s. 1.

11 N. Postman, Technopol. Triumf techniki nad kultura, tłum. A. Tanalska-Dulęba, Warszawa 1995 , s. $20-21$.

12 D. Hemment, The mobile effect, „Convergence” 11(2), 2005.

${ }^{13}$ L. Raine, B. Wellman, Networked. The New Social Operating System, Cambridge-London 2012, lok. 2255-2971 (książka w wersji mobi).

14 S. Hosokawa, The Walkman effect, „Popular Music” 4, 1984. 
czyna składać się z tzw. miękkich lokalizacji (soft location). Oznacza to, że za pośrednictwem stałej, niezależnej od ograniczeń fizycznych łączności możliwe staje się koordynowanie na bieżąco lokalizacji, szczególnie w trakcie umawiania się przez dwie (lub więcej) osoby. W ten sposób przestrzeń nie musi być już konkretnie określona i lokalizowana, lecz jest negocjowana w czasie rzeczywistym i podlegać może mikrokoordynacji ${ }^{15}$.

W podobny sposób można mówić o „miękkim czasie” (soft time) ${ }^{16}$ i to właśnie czas jest drugim elementem podlegajacym zmianom znaczeniowym wraz ze zmianami mobilności i rozpowszechnieniem technologii mobilnych. Miękki czas to czas negocjowalny, dający większe możliwości spóźnienia (gdyż można o tym łatwiej poinformować) lub zmiany terminu. W takich sytuacjach, gdy czas i terminarz nie są odgórnie ustalane, lecz raczej oddolnie i na bieżąco negocjowane, technologie mobilne moga wręcz zastępować tradycyjne zegarki ${ }^{17}$. Miękki czas wchodzi z kolei, także dzięki technologiom mobilnym, na miejsce „czasu martwego” (dead time) ${ }^{18}$. Nabiera wartości i staje się produktywny - a przynajmniej zyskuje wrażenie produktywności - w każdym miejscu i w trakcie każdej czynności. Nawet najbardziej banalne i chwilowe czynności, także najczęściej wskazywane w tym kontekście podróżowanie komunikacja miejska, zostają wypełnione znaczeniem dzięki korzystaniu z technologii mobilnych. Takie wypełnienie i „ożywienie” czasu współgra z bardziej ogólnymi i wspomnianymi wcześniej założeniami paradygmatu mobilności. Przywrócenie społecznej istotności przemieszczania się jest także rezultatem wypełnienia tych praktyk przez znaczący czas.

Po trzecie, nowe formy mobilności i technologii mobilnych wpływają na zmiany sposobów rozumienia i funkcjonowania tożsamości i podmiotowości. $\mathrm{Z}$ jednej strony dotyczy to poziomu jednostkowego i mikrospołecznego. Wskazuje się tu m.in. na takie elementy, jak: wpływ rozwoju technologicznego na indywidualizację ${ }^{19}$; większy potencjał niwelowania nierówności genderowych $\mathrm{w}$ porównaniu $\mathrm{z}$ technologiami stacjonarnymi ${ }^{20}$; zmiany sposobów rozumienia relacji intymnych rozpoczynanych i realizowanych za pośrednictwem technologii mobilnych ${ }^{21}$. Z drugiej strony omawiany temat odnosi się do poziomu makrospołecznego, ze szczególnym uwzględnieniem szeroko rozumianych uwarunkowań politycznych. Na ten aspekt - w szerszym kontekście nie tylko technologii mobilnych, lecz także nowych technologii cyfrowych w ogóle - zwracał już uwagę Manuel Castells, opisując wpływ Internetu na zmiany

${ }_{15}$ R. Ling, J. Donner, Komórka. Komunikacja mobilna, tłum. T. Płudowski, Warszawa 2012, s. 45 .

${ }^{16}$ L. Raine, B. Wellmann, op. cit., lok. 2641-2650.

${ }_{17}$ D.M. Sutko, A. de Souza e Silva, Location-aware mobile media and urban sociability, „New Media \& Society" 13(5), 2010, s. 809.

${ }_{18}$ J. Frith, Splintered space: hybrid spaces and differential mobility, „Mobilities” 7(1), 2012, s. 136 .

${ }^{19}$ M. Scheller, J. Urry, op. cit., s. 221-222.

${ }^{20} \mathrm{Ch}$. Mörtberg, Heterogeneous images of (mobile) technologies and services: a feminist contribution, „NORA: Nordic Journal of Women Studies” 11(3), 2003.

${ }^{21}$ G. Khunou, Making love possible: cell phones and intimate relationships, „African Identities" 10(2), 2012. 
polityczne na Bliskim Wschodzie ${ }^{22}$. Wartość dodana technologii mobilnych dotyczy tu w głównej mierze uwidzialniania wydarzeń bezpośrednio w miejscu ich dziania się ${ }^{23}$. Virginia Nightingale ${ }^{24}$ określa tego typu działania mianem mobilism - odnosząc się do takiej formy aktywizmu obywatelskiego, która wykorzystuje technologie mobilne do publicznego rozpowszechniania treści politycznych i relacji z wydarzeń politycznych. Polityka jest tu oczywiście rozumiana w szeroki sposób, tzn. nie tylko jako jej instytucjonalne przejawy, lecz także jako działalność choćby ruchów społecznych czy emancypacyjnych. Mobilism w bezsprzeczny sposób zmienia rozumienie polityki, podkreślając jej oddolny i obywatelski aspekt.

Widać więc, że przyjęcie założeń paradygmatu mobilności - większe znaczenie przemieszczania się i rozwój technologii mobilnych - wpływaja na zmiany społecznego rozumienia pojęć i zjawisk. Można wręcz stwierdzić, że w ramach omawianego paradygmatu odwrócone zostaja pewne założenia teoretyczne dotyczące opisu współczesnego świata społecznego. Anthony Giddens wskazuje na rozdzielenie czasu i przestrzeni jako jedną z głównych cech późnej nowoczesności ${ }^{25}$. Tymczasem w paradygmacie mobilności czas i przestrzeń nie tylko pozostają wciąż ze sobą połączone, gdyż wspólnie wyznaczają sposoby doświadczania i rozumienia mobilności, lecz ich związki sa nawet bardziej ścisłe. Tę perspektywę ciekawie opisuja Nikhilesh Dholakia, Ian Reyes i Jeniffer Bonoff ${ }^{26}$. Zdaniem tych autorów w definiowaniu i rozumieniu mobilności równie ważne, jak przestrzeń i miejsce, jest tempo. Dotyczy to m.in. takich aspektów, jak: zasady wchodzenia w relacje interpersonalne, możliwości rejestrowania informacji, stopień centralizacji, możliwości personalizacji urzadzeń itd. Różne opisywane tempa technologii i mobilności - legato, staccato i tempo izochroniczne - oparte są więc na obserwacji, że sposób korzystania z technologii związany jest $\mathrm{z}$ odczuwaniem oferowanego przez nie tempa, przejawiającego się w relacjach w czasie i przestrzeni.

\section{ROZUMIENIE MOBILNOŚCI W ŚWIETLE BADAŃ EMPIRYCZNYCH}

Ograniczanie się do praktyk indywidualnego i zbiorowego przemieszczania się nie jest jedynym uproszczeniem $\mathrm{w}$ badaniach i analizach mobilności. Innym jest brak zainteresowania tym, jak w ogóle przez uczestników życia

${ }^{22}$ M. Castells, Sieci oburzenia i nadziei, tłum. O. Siara, Warszawa 2013.

${ }^{23}$ L. Rhue, A. Sundararajan, Digital access, political networks and the diffusion of democracy, „Social Networks” 36, 2014, s. 43.

${ }^{24}$ V. Nightingale, The camera phone and online image sharing, „Continuum: Journal of Media \& Culture" 21(2), 2007.

${ }^{25}$ A. Giddens, „Nowoczesność i tożsamość. Ja i społeczeństwo w epoce późnej nowoczesności”, tłum. A. Szulżycka, Warszawa 2006, s. 23.

${ }^{26}$ N. Dholakia, I. Reyes, J. Bonoff, Mobile media: from legato to staccato, isochronal consumptionscapes, „Consumption Markets \& Culture” 18(1), 2015. Wprawdzie autorzy odnoszą się w głównej mierze do mediów muzycznych, możliwe jest rozszerzenie ich propozycji na inne formy mediów. 
społecznego jest rozumiana mobilność. $\mathrm{Z}$ tego powodu badacze mogą być wciągani w pułapkę, szczególnie w kontekście badań jakościowych, gdy nieświadomie łączą ze sobą różne pola semantyczne przypisywane przez badanych mobilności i technologiom mobilnym.

Dlatego przedstawione powyżej założenia teoretyczne i wnioski z badań zastanych chciałbym rozwinać o dane i analizy zaczerpnięte $\mathrm{z}$ badań własnych. Przedstawiam poniżej cztery główne sposoby rozumienia mobilności, odnoszonej przede wszystkim do nowych technologii. Taki zakres tematyczny nie wyczerpuje oczywiście zagadnienia. Oparty jest on jednak na wspomnianym wcześniej założeniu o nieodłącznej relacji pomiędzy mobilnością a nowymi technologiami. Opis rozumienia mobilności w odniesieniu do nowych technologii może być więc wstępem do szerszego ujęcia tematu społecznych znaczeń mobilności. Jednocześnie już teraz możliwe staje się dostrzeżenie faktu, że mobilność jest postrzegana nie tylko jako cecha urządzenia, infrastruktury lub otoczenia, lecz także jako potencjał zależny od działań podejmowanych przez aktorów.

Projekt badawczy, z którego czerpię prezentowane dane, to „Możliwości i ograniczenia w korzystaniu z bankowości mobilnej w Polsce”. Był on realizowany w latach 2014-2015 przez Instytut Socjologii Uniwersytetu im. Adama Mickiewicza, a finansowany w ramach programu Santander Universidades, w którym Bank Zachodni WBK wspiera badania naukowe i szkolnictwo wyższe. Badania wykorzystywały metodę etnograficzna, zakładając bliską współpracę z wszystkimi 36 uczestnikami badania. Każdy z uczestników przez około miesiąc utrzymywał kontakt z zespołem badawczym, aby w ten sposób możliwe było poznanie nie tylko deklaracji, ale również nieuświadomionych zachowań i nawyków dotyczących korzystania z technologii mobilnych. Proces badawczy rozpoczynał się krótką rozmową wstępną z badanym. Następnie przez 2 tygodnie badany wypełniał codziennie dzienniczki opisujące sposoby korzystania z technologii mobilnych. Każdego dnia kilkakrotnie do badanych wysyłane też były w formie SMS-ów krótkie ankiety, które miały na celu poznanie tego, w jaki sposób w danym momencie badany korzystał z technologii mobilnych. Niezależnie od tych działań na smartfonach uczestników badania instalowane były aplikacje monitorujące sposoby korzystania z technologii. Wszystkie te zabiegi miały na celu ułatwienie i usprawnienie przebiegu wywiadów pogłębionych podsumowujących proces badawczy: z jednej strony przez urefleksyjnienie sposobów korzystania ze smartfonów, z drugiej - dzięki dostarczaniu dodatkowych materiałów (np. opracowań danych z aplikacji monitorującej) wykorzystywanych podczas wywiadów.

Przedstawione poniżej analizy odnoszą się do zrealizowanych wywiadów pogłębionych. Wywiady dotyczyły czterech bloków tematycznych: technologie i technologie mobilne, zarządzanie technologiami, aktywności smartfonowo-mobilne, bankowość mobilna. W niniejszym tekście odnoszę się przede wszystkim do pierwszego z tych bloków. Zrealizowane wywiady zostały spisane, a następnie przeanalizowane $\mathrm{z}$ wykorzystaniem programu MaxQda. $\mathrm{W}$ analizach wykorzystywano metodę typologiczną ${ }^{27}$.

${ }^{27}$ Za zgodą Banku Zachodniego WBK wykorzystano tu przygotowane przez autora fragmenty nieopublikowanego raportu badawczego: K. Chajbos, B. Mateja-Jaworska, D. Mroczkowska, 


\section{Możliwość przenoszenia}

Kluczową i najważniejszą cechą urządzenia definiowanego jako mobilne jest - co oczywiste i zdroworozsądkowe - możliwość jego przenoszenia. Urządzenie mobilne niejako „towarzyszy” użytkownikowi [04_K43_DM_HU] ${ }^{28}$ niezależnie od środowiska, w którym przebywa. Mobilność to w tym ujęciu niezależność od kontekstu sytuacyjnego, możliwość funkcjonowania w różnych sytuacjach, podporządkowanie się woli użytkownika. Podkreśla to podmiotowość użytkownika, decydowanie przez niego o tym, w jakich warunkach będzie korzystał z urządzenia.

Można wskazać na dwie najważniejsze cechy, które wpływają na mobilność urządzenia w kontekście jego przenoszenia. Pierwsza z nich to wielkość i waga urządzenia:

Z mobilnością kojarzy mi się coś lekkiego, małego, co... co po prostu nie będzie mi w jakiś sposób zawadzało czy... no po prostu wrzucę do torebki, czy do kieszeni i to jest cały czas ze mna. Tak mi się to kojarzy. Myślę, że tableta, gdybyśmy mieli, to też, też bym do tego zaliczyła [35_K26_W_NU].

Wielkość i waga to cechy, które decydują o tym, czy urządzenie można swobodnie zagospodarowywać w sensie jego poręczności. Uwzględnia to również także potrzebę, aby urządzenie „nie zawadzało” - aby nie zwracało uwagi wtedy, gdy z niego nie korzystamy, aby stawało się w tych sytuacjach w jakimś sensie niewidzialne, a tym samym niewyczuwalne przez nasze ciało.

Badani wskazują na okoliczności, które w odniesieniu do wielkości i wagi określają potencjał mobilności urządzenia. Pierwsza z nich to zmęczenie [02_ M32_DM_HU]. Urządzenie mobilne nie powinno zmuszać do wyjątkowego wysiłku przy jego przenoszeniu - zarówno jeśli chodzi o kształt, jak i wagę. Podkreśla się więc tu raz jeszcze znaczenie wygody podczas samej sytuacji przenoszenia. Druga okoliczność dotyczy zajmowanej przez nie przestrzeni:

No dla mnie to już by była przesada, jeżeli myślę o czymś mobilnym, to w mojej osobistej przestrzeni nie zajmuje tyle miejsca, żeby ingerować w kogoś, kto siedzi obok, gdzieś tam dużo czasu spędziłem w pociagach, jeżdżąc i podróżując, więc no te cztery miejsca w takim przedziale to osoba, jak siedzi, to wie Pan, ile jest tam miejsca. Gdybym się tam rozłożył z 21-calowym laptopem, to ingeruje w przestrzeń osoby, która jest tam obok i ma prawo czuć się no też tam swobodnie w miarę, no więc myślę, że ta mobilność jest też tam gdzieś granicząca [32_M32_MM_NU].

Innymi słowy, mobilność jako cecha ważna dla samego użytkownika nie może być czymś ingerującym w działania innych i utrudniajacym je. Rozpatrywane z perspektywy wielkości i wagi urządzenia granice mobilności powinny być więc zbieżne z granicami cielesności użytkownika. Ma to szczególne

W. Rapior, Ł. Rogowski, A. Szymańska-Palaczyk, M. Zawodna-Stephan, „Możliwości i ograniczenia w korzystaniu z bankowości mobilnej w Polsce".

${ }^{28}$ Odnośniki do wypowiedzi badanych są oznaczone w sposób: numer wywiadu_płeć i wiek badanych_miejsce zamieszkania $(\mathrm{DM}=$ duże miasto, $\mathrm{MM}=$ małe miasto, $\mathrm{W}=$ wieś)_kategoria użytkownika aplikacji mobilnej (HU = hard user, LU = light user, $\mathrm{NU}=$ non user). 
znaczenie właśnie wtedy, gdy odnosimy się do mobilności jako korzystania $\mathrm{z}$ urządzeń poza przestrzenią domową - a więc w taki sposób, gdy nie jesteśmy w stanie jednoznacznie zdefiniować warunków owych czynności. W tym kontekście ważne jest utrzymywanie swoistego „minimalizmu mobilności”.

Druga - obok wielkości i wagi - najważniejszą cecha, która wpływa na mobilność urządzenia w kontekście jego przenoszenia jest, stan baterii:

Urządzenie mobilne - najważniejszą kwestią jest to, aby działało poza źródłem zasilania, jeśli musi być pod prądem, to nie jest mobilne [23_M32_W_LU].

W tym sensie potencjał mobilności urządzenia jest przynajmniej częściowo zależny nie od użytkownika, lecz od infrastruktury zapewniającej dostęp do prądu. Tak samo wiek urządzenia może skutkować zmianami w „poziomie mobilności” - im starsza bateria, tym mniejsze możliwości jej ładowania i krótszy czas, gdy urządzenie może pracować bez podłączenia do prądu. W skrajnych sytuacjach stan baterii może sprawiać, że urządzenie zupełnie traci potencjał mobilności, pomimo spełniania opisanych wcześniej kryteriów wielkości i wagi:

Kiedy np. siada baterii, że trzeba co chwilę trzeba ładować, w takim momencie staje się praktycznie komputerem stacjonarnym, ponieważ musi być podłączone cały czas do ładowania [04_K43_DM_HU].

Opisane dwie cechy - wielkość i waga oraz stan baterii - skutkują powstawaniem własnych sposobów podtrzymywania potencjału mobilności przez użytkowników. Z wielkością i wagą związany jest przede wszystkim wybór miejsca korzystania z urządzenia:

Mam jakieś tam wygodne miejsce do siedzenia wybrane. Nie lubię korzystać z laptopa, gdzieś tam na kolanach. Jednak wolę przy, przy, przy jakiejś ławie czy biurku [35_K26_W_NU].

Wielkości i wagi dotyczy również ten aspekt podtrzymywania mobilności, który można określić jako zarządzanie układem własnego ciała:

Zawsze leżę na brzuchu i sobie ten. A jak coś zawsze muszę wyjść albo coś, bym musiał go odkładać znowu, potem go znowu brać i odkładać, więc trochę mi to ten. I pomyślałem, że tam by było lepiej. No zawsze sobie ruszę, kiedy się chce albo coś. Wiem, że żadnego kabla nie wyrwę, no i tak to chyba najbardziej chodzi [36_M19_W_NU].

Związane jest to $\mathrm{z}$ faktem, że w zależności od miejsca i przestrzeni zmienia się wygoda, z jaką korzysta się z urządzeń mobilnych. Czasami więc poszukujemy optymalnego układu w relacji urządzenie - przestrzeń - ciało, zakładając, że na komfort wpływa dopasowanie do siebie wszystkich tych trzech elementów.

W odniesieniu natomiast do baterii sposobem podtrzymywania mobilności jest zapewnianie dostępu do źródeł energii. Dotyczy to przede wszystkim sytuacji, w której jednym z kryteriów oceny i organizowania czasu i rozkładu dnia staje się temat odpowiedniego naładowania baterii w urządzeniach mo- 
bilnych. Noc jako czas odpoczynku nie tylko człowieka, ale również urządzenia staje się naturalnym i oczywistym okresem przeznaczonym na ładowanie baterii [03_M24_DM_HU]. Badani mówią również o tym, że urządzenia związane z ładowaniem (ładowarki, kable USB) stają się naturalnym elementem codziennego wyposażenia. Co jednak istotne, wspomina się raczej o tym, że nosi się je przy sobie, niż o tym, że są one wykorzystywane - szczególnie wtedy, gdy dotyczy do tabletu lub smartfona (których baterie są zreszta zazwyczaj trwalsze niż te w komputerach przenośnych). Można więc odnieść wrażenie, że temat baterii, jej trwałości i dostępu do prądu związany jest raczej z komfortem psychologicznym niż z rzeczywistą potrzebą pojawiającą się w sytuacji rozładowania baterii w smartfonach.

\section{Dostępność}

Kryterium dostępności dotyczy w dużym stopniu cech, które generalnie charakteryzują media cyfrowe. Chodzi tu przede wszystkim o interaktywność i zmiany dokonywane w czasie rzeczywistym, które odróżniają je od mediów analogowych (masowych), zwiąanych niekiedy z warunkowanym technologicznie lub instytucjonalnie opóźnieniem w przepływie informacji. Dostępność jako kryterium mobilności może być rozumiana na trzy sposoby. Po pierwsze, dostępność to łączność z innymi:

Jest Pani cały czas pod telefonem, można z Panią cały czas się skontaktować. Jeżeli nie wiem, ja bym coś potrzebował i Pani byłaby w stanie mnie nakierować, żebym ja sobie coś znalazł sobie nawet $\mathrm{w}$ moim pececie, to w tym momencie, no też. Może teraz źle to też ująłem, bo nie chodzi mi tylko o dostęp do Internetu, z tym że po prostu mobilność - jestem cały czas dostępny. Tak. Urządzenie mobilne sprawia to, że ja jestem dostępny dla innych osób niekoniecznie w kontakcie bezpośrednim [15_M22_DM_LU].

Urządzenie mobilne to urządzenie umożliwiające stały kontakt - ale nie tylko w sensie Internetu, ale także podłączenia do sieci komórkowych umożliwiających rozmowy telefoniczne, wysyłanie SMS-ów czy MMS-ów. Zapewniony zostaje w ten sposób stały kontakt o każdej porze dnia i nocy - zawsze wtedy, gdy użytkownik ma przy sobie włączone urządzenie mobilne. W tym sensie warto podkreślić, że taki sposób rozumienia mobilności jako dostępności dotyczy raczej osób prywatnych niż firm czy instytucji. W przypadku tych ostatnich kontakt nie bez powodu opiera się w dużej mierze na telefonach stacjonarnych, gdyż dostępność jest wyznaczana przez z góry określone godziny i dni pracy.

Po drugie, dostępność oznacza bliskość przestrzenną:

O mobilności decyduje przede wszystkim to, że jest na wyciagnięcie ręki od teraz, teraz mam możliwość wysłania maila, spojrzenia, przejrzenia Internetu w danym temacie, kiedy potrzebuje szybko np. sklep z narzędziami, których potrzebuje, bo jestem na jakimś uszkodzeniu mówię o swojej pracy i swoim temacie [17_M32_MM_LU].

W tym sensie dostępność to inaczej szybkość działania, możliwość podejmowania czynności na urządzeniu mobilnym zawsze wtedy, gdy pojawia się taka 
potrzeba/konieczność. Inaczej można ten sposób dostępności określić jako podręczność. Obecny jest tu również wymóg dostępności w sensie łączności.

Trzecim sposobem rozumienia dostępności jest aktualność i uniwersalność:

Powinno mieć wszystko w każdym jednym miejscu. Wszystkie techniki, które ma, powinny mieć możliwe w każdym jednym miejscu [25_M37_DM_NU].

Oznacza to postrzeganie urządzenia mobilnego jako konglomeratu różnych funkcji, dostępnych przez możliwość instalowania aplikacji. Chodzi tu nie tylko o funkcje komunikacyjne, ale również takie, które związane są z pozakomunikacyjnymi aspektami codziennego funkcjonowania (odtwarzacz muzyki, latarka itp.). W tym sensie urządzenie mobilne staje się swoista skrzynką narzędziowa, której funkcjonalność jest uzależniona od technologicznych możliwości dotyczących tworzenia aplikacji.

Sposobem podtrzymywania tak rozumianej mobilności jest dokonywanie aktualizacji [01_K22_DM_HU] - zarówno zainstalowanego oprogramowania, jak i plików, które znajdują się w pamięci urządzenia. W tym sensie aktualizacja związana byłaby np. z okresową zmianą plików muzycznych na smartfonie. Może to być związane również z aktualizacją danych kontaktowych (np. numerów telefonów) lub z kasowaniem już niepotrzebnych plików (np. nieudanych zdjęć).

Jednocześnie warto zwrócić uwagę, że opisana wcześniej dostępność w sensie stałych możliwości komunikacyjnych może wytwarzać w użytkownikach swoiste napięcie - zarówno w sensie pozytywnym, jak i negatywnym. Stan „bycia dostępnym” to jednocześnie stan nastawiania się na kontakt, spodziewania się go w każdym momencie ${ }^{29}$. Co za tym idzie, sytuacja ta może generować czynności odwrotne: nie tyle podtrzymywanie mobilności, ile jej neutralizowanie i zawężanie zasięgu. To wszystkie te momenty, gdy użytkownik celowo wyłącza się z dostępności/kontaktu: wyłączając lub wyciszając smartfona, wylogowujacc się z sieci, a nawet poszukując miejsc, w których nie ma zasięgu sieci komórkowych. W ten sposób izoluje się od niepożądanych w jakimś momencie kontaktów z innymi.

\section{3. Łączność z Internetem}

Trzeci sposób rozumienia mobilności podobny jest w dużym stopniu do poprzedniego i także dotyczy dostępności i włączenia do sieci komunikacyjno-informacyjnych. Jest on jednak często wspominany jako osobny, a jednocześnie różni się także jakościowo od poprzednio opisanego, dlatego warto potraktować go jako kolejny, odrębny sposób rozumienia mobilności. Dotyczy on tych sytuacji, gdy kryterium definiowania jakiegoś urządzenia jako mobilnego jest jego łączność z Internetem:

${ }^{29}$ B. Mateja-Jaworska, Ł. Rogowski, Zmęczenie w sieciach społecznych, „Kultura Współczesna” 2016, nr 3(91), s. 134-149. 
Urządzenie mobilne to jest takie urządzenie, które musi łączyć się z siecią - inaczej traci na mobilności, czyli z jednej strony musimy zakładać, żeby ten sygnał był, a z drugiej strony żebyśmy my mogli się tam do tego sygnału dostać [13_M53_DM_LU].

Mobilność oznaczałaby w tym sensie niezależność od stacjonarnej infrastruktury internetowej, co może być realizowane na dwa sposoby. Po pierwsze, to korzystanie z możliwości sieci bezprzewodowych, łączenie się z nimi w różnych miejscach. To jednak wymaga bądź posiadania danych dostępowych do tych sieci, bądź zdania się na sieci otwarte, które również mogą być mniej bezpieczne podczas użytkowania. Po drugie, i ważniejsze, to korzystanie z pakietów internetowych przypisanych do urządzeń mobilnych, przede wszystkim do kart SIM w smartfonach.

Można tu wskazać różną gradację tak rozumianej mobilności, która w dużym stopniu może być uzależniona od możliwości technologicznych oferowanych przez samo urządzenie:

No ja w tym momencie, mogę powiedzieć, że mam dwa urządzenia mobilne, to jest na pewno telefon i tablet, chociaż tablet w mniejszym znaczeniu, ponieważ do tableta potrzebuję WiFi bądź Internet, który sobie np. udostępnię z telefonu, a telefon mam mobilny tak naprawdę cały czas, tak. A tablet mam akurat taką wersję, to już nie jest tablet, w którym no nie ma tak jakby stałego dostępu do Internetu. No tam jest potrzebne właśnie, no w sumie jeśli mam komputer, to tak samo, jakbym miała laptopa, może w ten sposób, jakbym miała WiFi i telefon, chociaż jest bardziej praktyczne wzięcie tego tabletu niż, niż komputera [21_K23_W_LU].

We wszystkich wymiarach opisywanego kryterium nie chodzi o łączność dla samej łączności, ale o to, że dzięki połączeniu z Internetem użytkownik ma możliwość wykonywania na bieżąco aktywności i korzystania z aplikacji, które wymagają połączenia z siecią.

Zarządzenie zakresem łączności z Internetem jest również podstawowym sposobem rozszerzania mobilności w tym ujęciu. Sieć bezprzewodowa w miejscu zamieszkania dla większości badanych jest czymś naturalnym. W ten sposób możliwe staje się również oszczędzanie danych zawartych w pakiecie internetowym na karcie SIM:

W domu mam WiFi, jak nie mam dostępu, to się staram tego nie używać [19_K20_MM_LU].

Biorac pod uwagę, że niektórzy badani deklarują łączność urządzeń mobilnych z Internetem jedynie wtedy, gdy są one w zasięgu sieci bezprzewodowych - można stwierdzić, że zmienia się również w ten sposób potencjał mobilności urządzenia. Różne sposoby rozumienia mobilności są w tym sensie stosowane niejako zastępczo: dostępność i przenoszenie poza domem skutkuje odłaczaniem się od Internetu ze względu na wychodzenie poza zakres znanych sieci bezprzewodowych; i odwrotnie, podłączenie do Internetu przez WiFi zmniejsza znaczenie przenoszenia urządzenia. Co ważne, użytkownicy rzadko wspominają o Internecie mobilnym, oferowanym zazwyczaj przez sieci komórkowe, jako podstawowym sposobie dostępu do Internetu. Dominuje tu wciąż Internet stacjonarny. 


\section{Porównanie z analogowością/stacjonarnością}

Ostatni sposób rozumienia przez badanych mobilności nie dotyczy - tak jak to było wcześniej - wskazywania jakichś specyficznych cech i funkcji związanych z urządzeniami mobilnymi. Jest raczej związany z przeciwstawianiem ich innym, analogowym bądź stacjonarnym, sposobom rozumienia technologii. Innymi słowy, mobilność to cecha, która nie posiada cech urządzeń stacjonarnych/analogowych lub też posiada je w innym natężeniu lub w inny sposób. Wskazać można trzy szczegółowe sposoby takiego rozumienia mobilności. Pierwszy z nich to różnice w sposobie pisania i obsługi:

Bo w komputerze mam klawiaturę, z której mogę tak fajnie korzystać. W tablecie to jest tak samo, mimo że ma się tutaj panel dotykowy taki wielki, nawet pisząc coś, pojawia się klawiatura, to mój jest o tyle fajny, że ma dodatkowo, to jest asus, ma stacje dokującą też z klawiatura, dodatkową bateria, więc to jest też fajne, no i pomaga to właśnie w pisaniu pewnych rzeczy, między innymi także odpowiadaniu na maila. No a jeżeli chodzi o telefon, no to jeżeli przez telefon odpowiadam na maila, to, to jest naprawdę bardzo krótka wiadomość, bardzo krótka wiadomość, tam odpiszę później czy skontaktuję się tam w innym czasie [32_M32_MM_NU].

Znaczenie ma tu przede wszystkim forma interfejsu, różnice pomiędzy tradycyjną klawiatura a obsługą dotykowa. W tym kontekście również można wskazać na skalę mobilności: od komputerów przenośnych wyposażonych w klawiatury z klawiszami do smartfonów i tabletów, które obsługiwane sa w pełni za pośrednictwem dotyku. Pomiędzy nimi znajdują się urządzenia hybrydowe, które łączą w sobie różne formy interfejsów (np. tablet z dołączaną do niego klawiatura z tradycyjnymi klawiszami). Kluczowy jest tu fakt, że interfejs dotykowy utrudnia dokładną obsługę aplikacji. Jest przeznaczony raczej do szybkiego pisania krótkich wiadomości niż wykonywania precyzyjnych czynności. Wpływa to również na typ gier, które są przeznaczone do urządzeń mobilnych [03_M24_DM_HU] - raczej takich, które nie wymagają precyzji. Dotykowy interfejs urządzeń mobilnych zawęża więc zakres podejmowanych czynności, wymuszając, aby część z nich była wykonywana na urządzeniach innego typu.

Druga cecha związana z dystynkcją pomiędzy mobilnością a analogowością/stacjonarnościa jest $\mathrm{w}$ pewnym sensie przeciwieństwem pierwszej. Tak jak wyżej była mowa o trudnościach w posługiwaniu się interfejsami charakterystycznymi dla urządzeń mobilnych, tak tym razem chodzi o łatwość obsługi i ułatwienia w korzystaniu:

Bardzo lubię czytać książki, natomiast bardzo wygodnie jest czytać książki w formie elektronicznej, ponieważ, po pierwsze, jeśli chcę kupić tą książkę, to mam ją od razu, ponadto no praktycznie są takie promocje, że za kilka złotych. Kiedýs jeszcze na samym początku ściagałam, bo nie było tych książek, więc ściagałam wersje pirackie. W tej chwili już tego nie robię, bo są oryginalne, przede wszystkim są lepiej zrobione. Jeżeli chodzi o chodzenie do biblioteki, wiecznie płaciłam kary, bo wiecznie spóźniałam się z oddawaniem książek, w tej chwili nie mam już tego problemu. Teraz cokolwiek chcę, to ściagam sobie, kupuję bądź w tej chwili pojawiła się opcja, że można, płacąc abonament, mieć nieograniczony abonament do książek [43_M43_HU_DM]. 
Różnice pomiędzy utrudnieniami a wygodą związane są z zakresem aktywności podejmowanych przez użytkowników. Trudności pojawiają się wtedy, gdy użytkownik wchodzi w intensywniejsze, wymagające dokładności relacje z urządzeniem. Ułatwienia dotyczą natomiast tych momentów, gdy rola użytkownika jest bardziej bierna - tak jak w przytoczonym przypadku czytania książek elektronicznych. Czytnik jako urządzenie mobilne oferuje opcje, których brakuje tradycyjnym książkom, w tym łatwość zakupu.

Trzecia cecha odróżniająca urządzenia mobilne od innych dotyczy „zakresu auratyczności”, czyli ogólnego postrzegania formy, za pośrednictwem której prezentowane są treści:

\footnotetext{
Nigdy nie wezmę komórki czy tabletu do kościoła, nie, po pierwsze, sam bym się czuł dziwnie, a po drugie, nie wyobrażam sobie, żeby z tabletu czy komórki mówić tam brewiarz w kościele... Wiadomo, jak człowiek jedzie rowerem czy zatrzyma się w jakichś miejscach, to jest przydatne, bo telefon jest, a brewiarza - on nie zawsze jest taki chudy, generalnie to sa grube książki, więc nie zawsze to jest format kieszonkowy. Następne, że forma książkowa ona zawsze zapewnia taką sferę sacrum, coś, co jest nawiązaniem do czegoś, co wywodzi się... gdzieś ma człowiek świadomość z dalekiej przeszłości, no i gdzieś z tą tradycją Kościoła i duchowością się rozwija, tego w komórce nie ma [32_M32_MM_NU].
}

Ogólnie zwiąane jest to z przekonaniem, że są sytuacje i aktywności, do których lepiej nadają się media elektroniczne, w tym mobilne, a są również takie, do których lepiej pasują media tradycyjne, np. papierowe. Nie chodzi tu jednak o funkcjonalność, lecz właśnie o ogólniejszy charakter medium, związany np. z szacunkiem dla niektórych sytuacji i aktywności. Oparte jest to na założeniu o wyjątkowości, swoistym wyłączeniu z codzienności niektórych sytuacji, tak jak choćby w przypadku wspomnianych w cytacie czynności sakralnych. Stosowanie w ich przypadku urządzeń mobilnych (i szerzej: elektronicznych) może być problematyczne zarówno z punktu widzenia samego użytkownika (który traci w ten sposób poczucie wyjątkowości podejmowanych czynności), jak i jego otoczenia (które może być w ten sposób odczuwać negatywne emocje).

\section{PODSUMOWANIE}

Przedstawione powyżej sposoby rozumienia mobilności dotyczą w głównej mierze nowych technologii. Takie podejście jest uzasadnione wtedy, gdy już wcześniej główny nacisk w tekście został położony na technologiczne uwarunkowania mobilności i ich wpływ na znaczenia społeczne. Wyzwaniem empirycznym byłoby zweryfikowanie, w jakiej mierze zaprezentowane tu sposoby rozumienia mobilności pozostają aktualne także w innych jej formach i przejawach.

W przedstawionych analizach najistotniejszy sa jednak dla mnie nie tyle szczegółowe znaczenia przypisywane mobilności, ile raczej pewien ogólniejszy sposób jej traktowania. W każdym bowiem z opisywanych przypadków - możliwości przenoszenia, dostępności, łączności z Internetem, porównania ze sta- 
cjonarnościa - mobilność jest wypadkową relacji pomiędzy technologią i urządzeniem a jego użytkownikiem. Taka sieć relacji uwzględnia wiele bardziej szczegółowych wymiarów, o których była mowa powyżej. Mobilność jest więc zależna m.in. od relacji z ciałem, kontekstu przestrzennego, obecności innych osób, infrastruktury technologicznej, sieci kontaktów czy interfejsu.

To właśnie dlatego mobilność powinna być w badaniach empirycznych rozumiana nie jako stała cecha, ale jako potencjalność. Może ona funkcjonować na dwa sposoby. Po pierwsze, mobilność jako potencjalność jest aktywizowana lub blokowana w wybranych sytuacjach w zależności od kontekstu społeczno-sytuacyjnego i podejmowanych przez użytkowników działań. Po drugie, mobilność jako potencjalność funkcjonuje również jako stan świadomościowy i nastawienie użytkownika wobec technologii i kontekstu jej wykorzystywania. W tym ujęciu istotniejsza jest możliwość aktywizowania mobilności wtedy, gdy jest ona potrzebna, a nie sam fakt jej realizowania i wykorzystywania.

$\mathrm{W}$ takim ujęciu mobilność odchodzi od przyjmowanych często założeń esencjalistycznych i kieruje się w stronę „,antyesencjalizmu mobilności”. Jest więc traktowana nie jako cecha urządzenia, ale jako cecha sytuacji społecznej. W tym sensie mobilność jako potencjalność podkreśla również podmiotowość użytkowników, a zarządzanie mobilnością może być potraktowane jako element ponowoczesnych kompetencji społecznych.

dr Eukasz Rogowski

Uniwersytet im. Adama Mickiewicza w Poznaniu

lukasz.rogowski@amu.edu.pl

\section{MOBILITY AS A POTENTIALITY: WAYS OF UNDERSTANDING MOBILITY FROM THE PERSPECTIVE OF NEW TECHNOLOGIES AND THE PARADIGM OF MOBILITY}

$$
\text { Sum mary }
$$

The paper refers to the new mobilities paradigm as a perspective of describing contemporary social phenomena related to mobility and movement. It points to the interdependence between new forms of action taken by social actors and technological development. Three dimensions of the relationships between technology, mobility and social significance are described: the understanding of space, the understanding of time and identity of an individual and an agency. The most important assumption of the paper is that mobility is socially defined. Based on the results of a qualitative empirical research, several ways of social understanding of mobility are identified: portability, accessibility, internet connectivity, comparison with analogue/stationary systems. As a result, mobility has not been shown as a permanent social characteristic, but as a potentiality. 